\title{
CHANGES IN THE SOIL ORGANIC MATTER SUPPLY IN TOPSOIL AND SUBSOIL CAUSED BY CEREALS GROWN IN CROP ROTATIONS
}

\author{
V. Vlček, R. Stř́álková, J. Podešvová, E. Pokorný
}

Received: April 16, 2007

\begin{abstract}
VLČEK, V., STŘÁLKOVÁ, R., PODEŠVOVÁ, J., POKORNÝ, E.: Changes in the soil organic matter supply in topsoil and subsoil caused by cereals grown in crop rotations. Acta univ. agric. et silvic. Mendel. Brun., 2007, LV, No. 5, pp. 205-210

The paper evaluates seven years (1993-1999) of Soil organic matter supply monitoring in multifactor field trials conducted by the Agricultural Research Institute in Kroměříž, Czech Republic, (mean annual temperature $8.9^{\circ} \mathrm{C}$, total annual precipitation $599 \mathrm{~mm}$, medium Luvi-Haplic Chernozem). The studied plots were a part of nine-crop rotation: alfalfa the $1^{\text {st }}$ and $2^{\text {nd }}$ year, winter wheat, spring barley, sugar beet, spring barley, winter wheat, silage maize and spring barley. The Soil organic matter supply was measured on four plots: winter wheat after spring barley (var. 1), winter wheat after alfalfa (var. 2), spring barley after winter wheat (var. 3) and spring barley after sugar beet (var. 4). Soil samples were taken from April to July (14-day period) from topsoil $(0-30 \mathrm{~cm})$ and subsoil $(30-60 \mathrm{~cm})$. The content of Soil organic matter was determined by wet oxidation. Using bulk density, the C content (\%) was converted to $\mathrm{C}$ supply (t.ha ${ }^{-1}$ ). Average yield $\left(\mathrm{t} . \mathrm{ha}^{-1}\right.$ ) reached $6.54 \mathrm{t} / \mathrm{ha}$ (var. 1), $7.47 \mathrm{t} / \mathrm{ha}$ (var. 2), $6.52 \mathrm{t} / \mathrm{ha}$ (var. 3) and $7.20 \mathrm{t} / \mathrm{ha}$ (var. 4). Evaluation of the results was carried out by the analysis of variance and time changes by the second-degree regression analysis. Results demonstrated that Soil organic matter supplies were significantly changed in topsoil. The highest supplies were found in barley after sugar

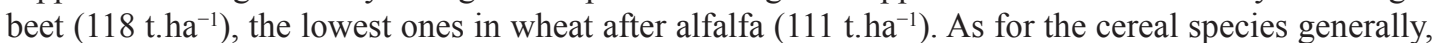
it was documented that in topsoils under barley the supplies were higher than under winter wheat. In subsoil, there were significant differences between wheat after alfalfa $\left(111 \mathrm{t} \cdot \mathrm{ha}^{-1}\right)$ and barley after wheat $\left(104\right.$ t.ha $\left.{ }^{-1}\right)$. As for a difference in the Soil organic matter supply in subsoil according to the cereal species the situation was contrary than in topsoil. Higher supplies were under wheat. Generally (topsoil and subsoil), the highest supply of Soil organic matter was in barley after sugar beet $\left(224 \mathrm{t}^{-h^{-1}}\right)$ and similarly in wheat after alfalfa $\left(222 \mathrm{t} \mathrm{ha}^{-1}\right)$. The smallest supply was in the variant of wheat after barley (217 t.ha ${ }^{-1}$ ). In topsoil, the average supply of humus was 114 t.ha ${ }^{-1}$ and that in subsoil was 107 t.ha ${ }^{-1}$ the difference being statistically significant.
\end{abstract}

soil organic matter supply, topsoil, subsoil, Luvi-Haplic Chernozem

Humus supply, composition and content dynamics in soils are associated with a number of factors and conditions of a soil forming process, ie flora, microorganisms, climate and bedrock (SOTÁKOVÁ, S., 1982).

Characteristic dynamic balance between mineralization and humification, between stabilization and activation of humus substances is formed in every soil type. Based on differences in the balanced components in each soil type, the following types of Soil organic matter regime can be defined: positive - continual gradual increase Soil organic matter (as a rule, at application of high organic fertilizer rates only), non-deficient - an equilibrium in Cox in the soil pro- 
file, deficient - substantial reduction, usually by loss of humified matter by erosion, mechanical surface treatments and others (SOTÁKOVÁ, S., 1986).

SALFELD and SOCHTIG (1977) suggested humus dynamic model that is based on 21 indicators. They differentiate between two types of organic matter dynamics in soil: (1) long-term and (2) short-term (cyclic) which is affected by plants and the climate.

Based on long-term stationary trials, KRUGLOV and PROŠL'AKOV (1979) suggest using a regression equation to calculate humus supply in arable land. According to this equation, the humus supplies in arable land increase together with the decrease in proportions of root crops in a crop rotation, farmyard manure and mineral fertilizer application, and with clay content.

BADALÍKOVÁ and HRUBÝ (1999) demonstrated that the humus content decreased along with the depth of soil tillage. The five-year results of physical properties enable to calculate particle density that depends also on humus content (inversely proportionally). However, their results do not confirm this statement since the particle density increased from 2.59 g. cm ${ }^{-3}$ in variants "minimum tillage" and "notillage" to $2.61 \mathrm{~g} . \mathrm{cm}^{-3}$ in variant "tillage". It was confirmed that minimum tillage practices increased water content, and thus grain yields of cereals were higher under dry conditions at the location Hrušovany near Brno. The decrease in minimum air content from $15.2 \%$ in variant "tillage" to $10.6 \%$ in variant "no-tillage" can be considered as a basic change.

A favourable effect of humus on physical, chemical and biological properties of arable land is generally well-known. According to KÖRSCHENS (1990) the increase in soil carbon content by $0.1 \%$ increase water retention by $0.5-0.6 \%$, cation exchange capacity by 0.7 meq. $\mathrm{kg}^{-1}$, porosity by $1 \%$ and decrease bulk density by $0.01-0.02$ g. $\mathrm{cm}^{-3}$. Soil organic matter is a source of substances and energy for soil microorganisms, positively affects soil structure, increases availability of plant nutrients, and thus directly influences plant growth (HODGES, R.D., 1991).

The increase in the $\mathrm{C}: \mathrm{N}$ ratio in tilled and mineral-fertilized soil suggests that nitrogen substances of soil organic matter are proner to decomposition and mineralization than the substances without nitrogen. Average numbers of free-living diasotrophic bacteria were lower in cultivated variants than in the control during the whole time of conducting the experiment. These bacteria were almost eliminated in minerallyfertilized variants. The results of assessment of nitrification activity confirmed positive effect of organic fertilization and inhibiting effect of high rates of mineral fertilization on this activity (KUBÁT, J., et al. 1999).

Organic fertilization in long-term experiments increased the average number of bacteria to about double in comparison with non-fertilized controls. In minerally-fertilized variants, the number of bacteria decreased to nearly half compared to the control. It is obvious that the occurrence of bacteria depends on fresh organic matter rather than on total carbon content in soil (KUBÁT, J., et al. 1999).

\section{MATERIAL AND METHODS}

The Soil organic matter supply was investigating at the location Kroměříz in central Moravia. Agricultural lands in this region rank among the most fertile lands in the Czech Republic. Considering the geographical location, the country is included in Central-European climatic zone. Effects of mild maritime climate prevail in the western part and effects of the continental climate are more pronounced towards the east.

Ivestigated in the soil Soil organic matter supply were in multifactorial field trials at the Agricultural Research Institute Kroměříž, Ltd. over the time period 1993-1999 (founded in 1972). The locality belongs to area T3 (warm, slightly humid) with the mean annual temperature $8.7{ }^{\circ} \mathrm{C}$ and total annual precipitation $599 \mathrm{~mm}$. According to the FAO classification, the soil belongs to Luvi-Haplic Chernozem. Clay-loam soil (content of particles $<0.01 \mathrm{~mm}$ accounts for $42 \%$ ).

In the topsoil $(0-30 \mathrm{~cm})$, total nitrogen content $(\mathrm{Nt})$ is $0.22 \%$, Soil organic matter content $2.35 \%$, HA:FA 0.88 and $\mathrm{pH} / \mathrm{KCl} 6.60$ is neutral. Cation exchange capacity (220 meq. $\mathrm{kg}^{-1}$ ) is medium, sorption complex is saturated to $80 \%$, contents of magnesium $\mathrm{Mg}^{2+} 8 \%$, potassium $\mathrm{K}^{+} 4 \%$ and calcium $\mathrm{Ca}^{2+} 67 \%$ in sorption complex are medium. The content of available phosphorus (according to Egner), $155 \mathrm{mg} \cdot \mathrm{kg}^{-1}$, is very high.

In the subsoil, total nitrogen content $(\mathrm{Nt})$ is $0.16 \%$, Soil organic matter content $1.72 \%$, HA:FA 0.92 and $\mathrm{pH} / \mathrm{KCl} 6.71$ is neutral. Cation exchange capacity (234 meq. $\mathrm{kg}^{-1}$ ) is medium, sorption complex is saturated to $80 \%$, content of magnesium $\mathrm{Mg} 9 \%$, potassium K $1.6 \%$ and calcium $\mathrm{Ca} 70 \%$ in sorption complex are medium. The content of available phosphorus (according to Egner), $60 \mathrm{mg} \cdot \mathrm{kg}^{-1}$, is good.

The 9-years crop rotation with $62.5 \%$ of cereals (alfalfa $1^{\text {st }}$ and $2^{\text {nd }}$ year, winter wheat, spring barley, sugar beet, spring barley, winter wheat, maize for silage, spring barley). To measure supply of Soil organic matter, the following variants were selected: winter wheat after spring barley (variant 1), winter wheat after alfalfa (variant 2), spring barley after winter wheat (variant 3 ) and spring barley after sugar beet (variant 4$)$. Plots have 8 square meters $(2 \times 4 \mathrm{~m})$. On the plot is medium ploughing and standard prepare of soil for sowing. Soil samples were taken twice a month each year (at 14-day period) in the period from late April to the end of July ( 7 samplings per 
year) from topsoil $(0-30 \mathrm{~cm})$ and subsoil $(30-60 \mathrm{~cm})$. Undisturbed samples were taken using Kopecký's cylinders (in 3 replications) from the depth of $10-15 \mathrm{~cm}$ and $35-40 \mathrm{~cm}$ to determine bulk density. At the same sampling points, soil samples were taken from topsoil $(0-30 \mathrm{~cm})$ and subsoil $(30-60 \mathrm{~cm})$ in which content of oxidable carbon was assessed by wet oxidation in chromium-sulphur mixture and converted to Soil organic matter (JANDÁK, J., et al. 1991). Soil organic matter content (\%) was converted to Soil organic matter supply (t.ha ${ }^{-1}$ ) using soil bulk density.

In the period from April to July in 1993-1999, mean temperature was $15.8^{\circ} \mathrm{C}$ and total precipitation $246 \mathrm{~mm}$. The varieties of winter wheat Hana (19931994) and Samanta (1995-1999) and spring barley Akcent (1993-1999) were grown in these tim eperiods. Mineral fertilizers $\left(\mathrm{N}: \mathrm{P}_{2} \mathrm{O}_{5}: \mathrm{K}_{2} \mathrm{O}\right.$ in $\mathrm{kg} \cdot \mathrm{ha}^{-1} \cdot$ year $\left.^{-1}\right)$ were applied in autumn at the average rate of $61: 67: 101$ (var. 1), 46:67:105 (var. 2), 9:58:95 (var. 3) and 0:55:111 (var. 4), respectively. Winter wheat did not receive any additional nitrogen during the vegetation period. Spring barley was not fertilized with nitrogen before seeding or till the 3-leaf stage. In 1993-1999, average grain yields were 6.54 t.ha ${ }^{-1}$ (var. 1), 7.47 t.ha $^{-1}$ (var. 2), 6.52 t.ha $^{-1}$ (var. 3) and 7.20 t.ha $^{-1}$ (var. 4).
The results were evaluated by the analysis of variance (LSD test, $\mathrm{P}>0.05)$ and time changes by the second-degree regression (tested by correlation index) using software Excel (ORVIS, W. J., 1996) and Statgraphics (KOSCHIN, F., et al. 1992).

\section{RESULTS AND DISCUSSION}

Average supply of Soil organic matter in soil ran-

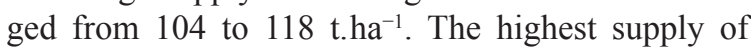
Soil organic matter (118 t.ha $\left.\mathrm{t}^{-1}\right)$ was found in topsoil in var. 4 (spring barley after sugar beet). The lowest supply of Soil organic matter $\left(104\right.$ t.ha $\left.{ }^{-1}\right)$ was found in subsoil in var. 3 (spring barley after winter wheat).

The results of 7-year investigation demonstrated that the changes in content of Soil organic matter in topsoil $(0-30 \mathrm{~cm})$ are statistically significant. The highest supply (118 t.ha $\left.{ }^{-1}\right)$ was found in topsoil (0$30 \mathrm{~cm}$ ) in var. 4 (spring barley after sugar beet) and the lowest one $\left(111\right.$ t.ha $\left.^{-1}\right)$ in var. 2 (winter wheat after alfalfa). If we consider that the difference of $7 \mathrm{t}$ generated from late April to the end of July, such a difference was substantial. It is generally reported that supplies under spring barley are higher than those under winter wheat, which was confirmed by our results (Graph 1).

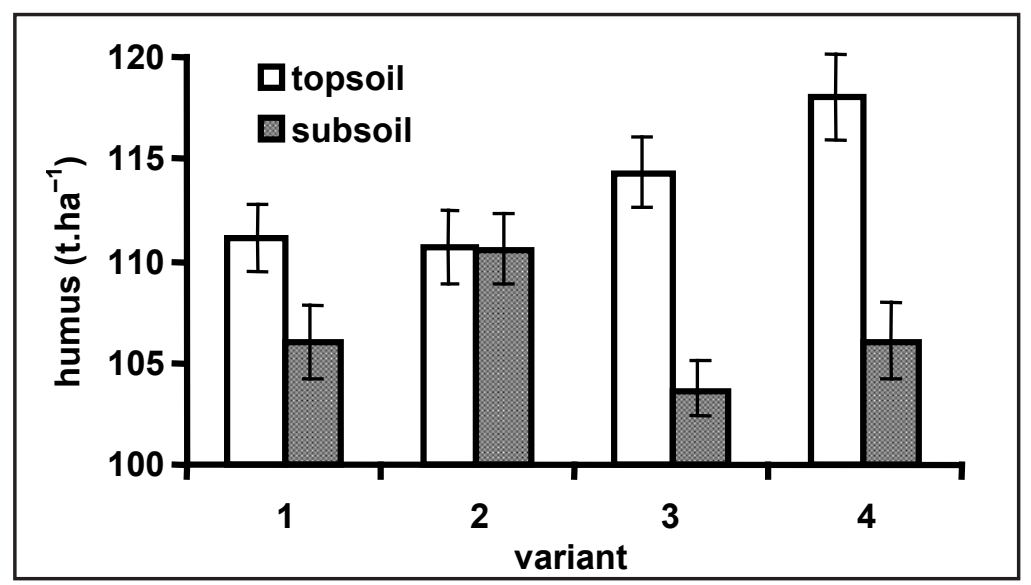

1: Average supply of humus in topsoil and subsoil $\left(t . h a^{-1}\right)$

A statistically significant difference was also found in subsoil (30-60 cm) between var. 2 (wheat after alfalfa) with the supply of Soil organic matter $111 \mathrm{t}^{\mathrm{h} \mathrm{ha}^{-1}}$ and var. 3 (barley after cereal crop) with the supply of 104 t.ha $^{-1}$. Here, higher supply of Soil organic matter were found under winter wheat (Graph 1). It means that the situation in subsoil is opposite to topsoil.

The highest supply of Soil organic matter in the of 0-60 cm layer (topsoil and subsoil) was found in var. 4 (barley after sugar beet) 224 t.ha ${ }^{-1}$ and similarly in var. 2 (wheat after alfalfa) 222 t.ha $\mathrm{h}^{-1}$. The lowest supply was found in var. 1 (wheat after barley) 217 t.ha ${ }^{-1}$. An average supply was 114 t.ha ${ }^{-1}$ in topsoil and 107 t.ha $^{-1}$ in subsoil at the statistically significant difference of 7 t.ha ${ }^{-1}$. The dynamics of Soil organic matter during the growing season is illustrated in Graphs 2 and 3. 


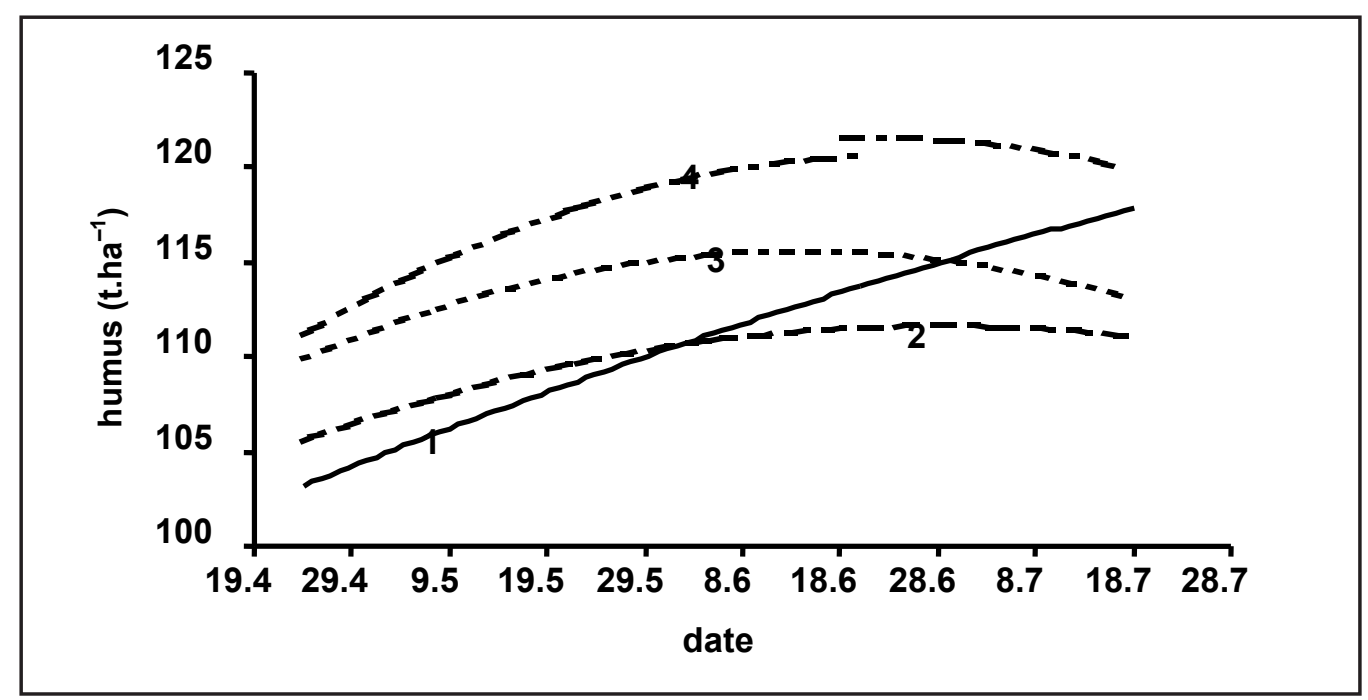

2: Dynamics Supply of Humus $\left(\right.$ t.ha $\left.{ }^{-1}\right)$ in topsoil $(0-30 \mathrm{~cm})$

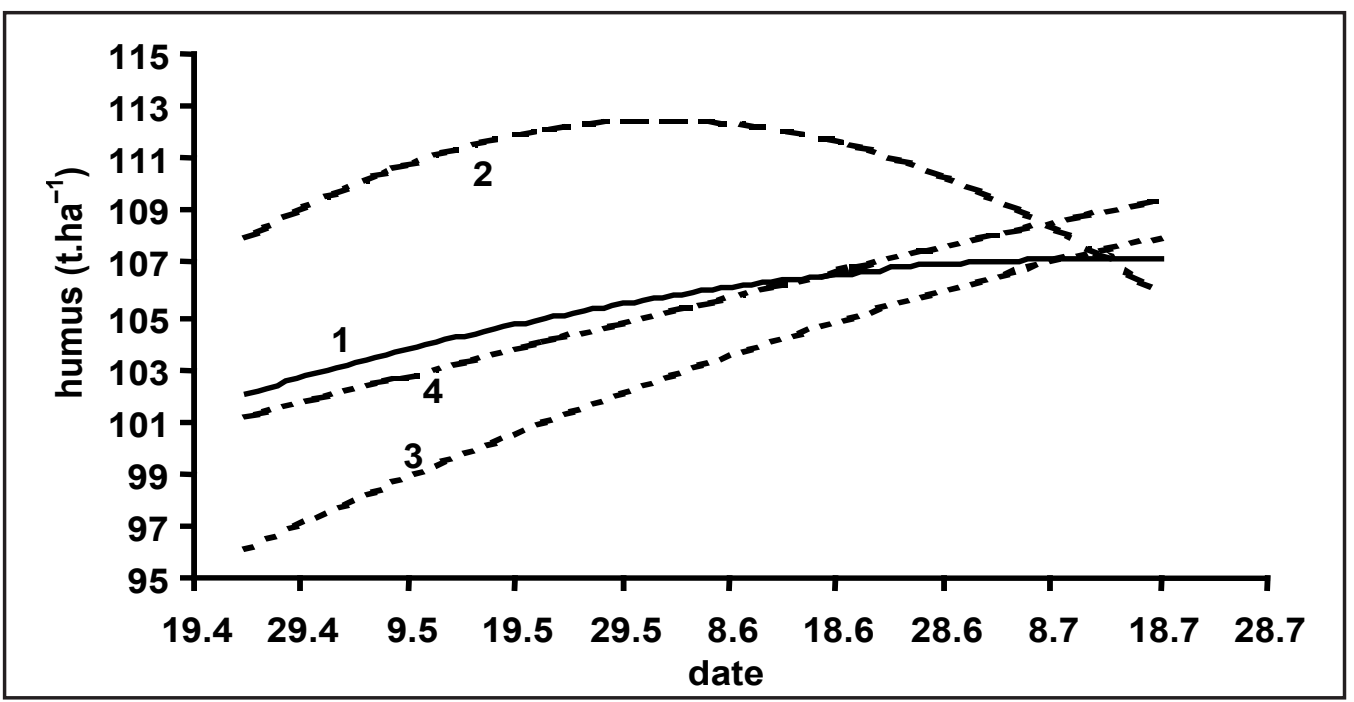

3: Dynamics Supply of Humus $\left(\right.$ t.ha $\left.{ }^{-1}\right)$ in subsoil $(30-60 \mathrm{~cm})$

Furthermore, it is generally claimed that intensive soil tillage to root crops aggrevates, to a certain extent, its status since it speeds up organic matter decomposition. By contrast, favourable effects of root crops in the crop rotation and their value as a forecrop are caused by regular application of organic and mineral fertilizers (KOSTELANSKÝ, F., et al. 1998). Indeed, after sugar beet there was a certain unbalance in soil organic matter between topsoil and subsoil, nevertheless, a total supply of Soil organic matter in the horizon of 0-60 cm was highest after sugar beet (var. 4, Graph 1). However, such unbalance between topsoil and subsoil was noticed also after cereal crops. In this case, the situation is opposite since the total supply of Soil organic matter was lowest in var. 1 and 3 (Graph 1). The difference between the lowest var. 1 (winter wheat after spring barley) and the highest var. 4 (spring barley after sugar beet) in the entire hori-

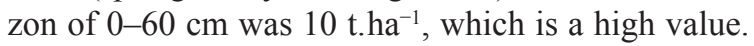
Thus, it is impossible to accept generally the opinion, that humus supplies in arable land decrease at increasing the proportion of root crops in the crop rotation as reported by KRUGLOV and PROŠLAKOV (1979). In these variants, positive effects of crop alternation on soil organic matter and, on the contrary, negative effects of cereal continuous cropping were found. Today, when soil care is highlighted more than yields, this study could change the view of continuous cereal growing. In the future, it would be interesting to observe these changes in long-term trials with cereal crops. 
I: Supply of humus in topsoil - analysis of variance

\begin{tabular}{|l|c|r|c|c|c|}
\hline Source of variation & Sum of squares & DF & Mean of squares & F-ratio & Significance level \\
\hline Between groups & 1209700,374 & 3 & 556,791 & 3,467 & 0,0170 \\
\hline Within groups & 31209384,912 & 192 & 163,463 & \multicolumn{2}{|c}{} \\
\cline { 1 - 4 } Total & 33085,286 & 195 & &
\end{tabular}

II: Supply of humus in topsoil - cogency between variants

\begin{tabular}{|c|c|c|c|}
\hline Variation & 4 & 3 & 2 \\
\hline 1 & $*$ & & \\
\hline 2 & $*$ & & \multicolumn{2}{|l}{} \\
\hline 3 & & \multicolumn{2}{|l}{} \\
& &
\end{tabular}

III: Supply of humus in subsoil - analysis of variance

\begin{tabular}{|l|c|r|c|c|c|}
\hline Source of variation & Sum of squares & DF & Mean of squares & F-ratio & Significance level \\
\hline Between groups & 1209218,574 & 3 & 406,191 & 2,91 & 0,037 \\
\hline Within groups & 26796,061 & 192 & 138,563 & & \\
\hline Total & 28014,635 & 195 & & & \\
\hline
\end{tabular}

IV: Supply of humus in subsoil - cogency between variants

\begin{tabular}{|c|c|c|c|}
\hline Variation & 4 & 3 & 2 \\
\hline 1 & & & \\
\hline 2 & & $*$ & \multicolumn{2}{|c|}{} \\
\hline 3 & & \multicolumn{2}{|c}{} \\
\cline { 1 - 2 } & &
\end{tabular}

V: Regression function of changes in suplly of humus in topsoil

\begin{tabular}{|c|l|c|c|}
\hline Variant & \multicolumn{1}{|c|}{ Equation } & $\mathrm{R}$ & $\mathrm{R}^{2}$ \\
\hline 1 & $\mathrm{y}=-0,004 \mathrm{x}^{2}+0,3069 \mathrm{x}+73,328$ & $0,921 *$ & 0,850 \\
\hline 2 & $\mathrm{y}=-0,0014 \mathrm{x}^{2}+0,5166 \mathrm{x}+65,079$ & $0,646 *$ & 0,418 \\
\hline 3 & $\mathrm{y}=-0,0022 \mathrm{x}^{2}+0,7275 \mathrm{x}+55,169$ & $0,607 *$ & 0,369 \\
\hline 4 & $\mathrm{y}=-0,0025 \mathrm{x}^{2}+0,8912 \mathrm{x}+42,124$ & $0,730 *$ & 0,533 \\
\hline
\end{tabular}

VI: Regression function of changes in suplly of humus in subsoil

\begin{tabular}{|c|l|c|c|}
\hline Variant & \multicolumn{1}{|c|}{ Equation } & $\mathrm{R}$ & $\mathrm{R}^{2}$ \\
\hline 1 & $\mathrm{y}=-0,008 \mathrm{x}^{2}+0,3042 \mathrm{x}+77,347$ & $0,547 *$ & 0,300 \\
\hline 2 & $\mathrm{y}=-0,003 \mathrm{x}^{2}+0,9355 \mathrm{x}+40,628$ & $0,600 *$ & 0,361 \\
\hline 3 & $\mathrm{y}=-0,0006 \mathrm{x}^{2}+0,3359 \mathrm{x}+65,707$ & $0,856 *$ & 0,734 \\
\hline 4 & $\mathrm{y}=-0,0001 \mathrm{x}^{2}+0,1368 \mathrm{x}+87,1$ & $0,625 *$ & 0,391 \\
\hline
\end{tabular}

\section{SOUHRN}

Změny zásoby půdní organické hmoty v ornici a podorničí způsobené obilninami pěstovanými v osevních sledech

Práce vyhodnocuje sedmiletá (1993-1997) pozorování zásoby humusu v ornici a podorničí v osevních sledech polyfaktoriálních polních pokusů (62,5 \% obilnin) Zemědělského výzkumného ústavu v Kroměříži (průměrná roční teplota $8,9^{\circ} \mathrm{C}$, roční suma srážek $599 \mathrm{~mm}$, půda je stř̌ední černozem luvická). Na variantách: 1 - pšenice ozimá po ječmenu jarním, 2 - pšenice ozimá po vojtěšce, 3 - ječmen jarní po pšenici ozimé a 4 - ječmen jarní po cukrovce byly ve čtrnáctidenních intervalech, v období od třetí dub- 
nové do třetí červencové dekády, odebírány porušené vzorky z hloubek 0-30 cm a 30-60 cm a stanoven obsah humusu (spálením v chromsírové směsi). Pomocí objemové hmotnosti byl obsah v \% přepočítán na zásobu v t/ha. Z výsledků pokusů plyne, že největší zásoby humusu jsou celkově (ornice i podorničí) ve variantě číslo 4 - tzn. ječmen po cukrovce (224 t/ha), podobně jako ve variantě číslo $2-$ tzn. pšenice po vojtěšce $(222$ t/ha). Ve variantě číslo 2 však byl vyrovnanější poměr mezi zásobou humusu v ornici a podorničí. Jako problematické se zde ukázalo pěstování obilniny po obilnině - v našem př́ípadě varianta číslo 1 - pšenice ozimá po ječmeni jarním, kdy byla zásoba humusu (v ornici i podorničí) ze všech variant nejnižší (214 t/ha). V této práci se ukázal negativní důsledek pěstování obilnin po sobě, a to úbytek půdní organické hmoty, až o 10 t/ha (v ornici i podorničí dohromady - viz graf 1 - varianta 1 a 4). V ornici je průměrná zásoba 114 t/ha a v podorničí 107 t/ha, přičemž rozdíl je statisticky průkazný. Pozitivní vliv na průměrný obsah humusu v ornici a podorničí má stř́idání plodin v osevních postupech. Naopak jako nevhodné se ukázalo následné pěstování obilnin.

V budoucnu by bylo zajímavé sledovat tyto změny na plochách, kde se již několik desítek let pokusně pěstují obilniny po sobě.

pPůdní organická hmota, ornice, podorničí, černozem luvická

This study is financially supported by the Ministry of Education, Youth and Sports (MSMT), Czech Republic. Project number 2532885901 "Optimisation of sustainability factors of crop production based on the development of genetic and breeding, diagnostic and decision-making methods" and is one of outcomes of the research intention of MSM 4321 00001, and is it one of the outcomes of the research intention: Biological and Technological Aspects of Sustainable of controlled Ecosystems and their Adaptation for Change of Climate (c.MSM6215648905).

\section{REFERENCES}

BADALÍKOVÁ, B., HRUBÝ, J.: The change of quality of humus in soil by continuous growing of winter wheat. 1999 In: Výživa rostlin, kvalita, produkce a zpracovatelské využití. Sborník referátů z konference Brno, MZLU, p. 57-60.

HODGES, R. D.: Advanced in soil organic matter research: The impact on agriculture and the environment. 1991 In Wilson W. S. (ed.): Royal Society of Chemistry. Cambridge.

JANDÁK, J. et al.: Cvičení z půdoznalství. VŠZ Brno, $1991.213 \mathrm{p}$.

KÖRSCHENS, M.: Humic substances as an active part of the system soil-plant. Praha, 1990. p. 42-53.

KOSCHIN, F. et al.: Statgraphics aneb statistika pro každého. Grada Praha, 1992. 360 p.

KOSTELANSKÝ, F. et al.: Obecná produkce rostlinná. MZLU Brno 1998. 212 p.

KRUGLOV, L. V., PROŠLAKOV, A. A.: Vospolne- nije gumusa v pachotnych počvach nečernozemnoj polosy. 1979. Počvovedenije, 5: 5-17.

KUBÁT, J., NOVÁKOVÁ, J., CERHANOVÁ, D., APFELTHALER, R.: Cyklus organického dusíku, amonifikačni aktivita $v$ dlouhodobém polním pokusu. 1999 Rostlinná výroba, 45, p. 397-402.

NĚMEČEK, J. et al.: Taxonomický klasifikační systém pidd $\check{C} R$. ČZU Praha, 2001. 79 p.

ORVIS, W. J.: Microsoft Excel pro vědce a inženýry. Computer Press Praha, 1996. 498 p.

SALFELD, J. CH., SOCHTIG, H.: Composition of the soil organic matter system depending on soil type and land use. 1977. In: Soil Organic Matter Studies. Vienna.

SOTÁKOVÁ, S.: Organická hmota a úrodnost' pôdy. Príroda Bratislava, 1982. 234 p.

SOTÁKOVÁ, S.: Zákonitosti recentného humusotvorného procesu a humusový režim v hnedozemi. 1986. In: Klasifikácia a hodnotenie pôdnych režimov. Bratislava.

\section{Address}

Ing. Vítězslav Vlček Ph.D., Doc. Ing. Eduard Pokorný, Ph.D., Ústav agrochemie, půdoznalství, mikrobiologie a výživy rostlin, Mendelova zemědělská a lesnická univerzita v Brně, Zemědělská 1, 61300 Brno, Česká republika, e-mail: xvlcek1@mendelu.cz, pokorny@mendelu.cz, Ing. Radomíra Střalková, Ph.D., Jitka Podešvová, Agrotest fyto, s. r. o., Havlíčkova 2787/121, 76701 Kroměříž, Česká republika, e-mail: stralkov@ vukrom.cz 